Island Studies Journal, Vol. 9, No. 1, 2014, pp. 79-102

\title{
Community sustainability in the year-round islands of Maine
}

Samuel A. McReynolds

University of New England

Biddeford and Portland, Maine

USA

smcreynolds@une.edu

\begin{abstract}
This article examines community sustainability in the year-round islands of Maine, USA, with a critical focus on the impacts of seasonal residents on sustainability. The context of this research is to provide foundational material to determine and measure sustainability in island communities. Data examined includes population, housing, housing affordability, housing occupancy, property valuation, and taxable sales. Food availability is an important secondary consideration. The overall finding is that the island communities as they have historically existed are not likely to be sustainable but may become sustainable in a new form. The overall impact of seasonal residents on sustainability is inconclusive except that there is a clear negative impact in the area of housing. Directions for additional research are discussed.
\end{abstract}

Keywords: community indicators; community sustainability; development; food availability; island life; Maine

(C) 2014 - Institute of Island Studies, University of Prince Edward Island, Canada.

\section{Introduction}

Maine's islands are a beautiful and dramatic natural environment that is unparalleled in the United States. They are home to the only natural fjord in North America, rich fishing grounds, many bays and coves, and geographically the closet region in the United States to Europe. The coast line of Maine is only 400 kilometers, however, there are nearly 5,650 kilometers of tidal coast line in the state, fourth only to Alaska, Florida, and Louisiana (Beaver, 2006). The reason for the extended tidal coast line is the fact that there are some 3,170 islands along the rocky coast of Maine, more than in the entire Caribbean or in Polynesia (Maine Islands Coastal Registry, 1975).

Maine has been called the place where America really began (Caldwell, 2001). If Maine is where America began, then its first communities were on the islands of Maine. These islands have played, and continue to play, a critical role in the history, economy, environment, and social life of the state. The nature of this role and of these communities, however, is changing. In recent decades, there has been an expansion of seasonal residents and a conversion of island homes to seasonal units.

This paper addresses the questions: are the island communities of Maine sustainable; and does the expansion of seasonal home ownership in Maine's year-round islands maintain, enhance or detract from this sustainability? In addressing this question, this study will delineate key elements in understanding community sustainability in the year-round islands of Maine and then provide an analysis of related data. The goal of the research is twofold. First, it will use historical and secondary demographic data, as well as primary data on food availability, to 


\section{S. A. McReynolds}

provide a descriptive analysis of sustainable conditions, particularly as they are impacted by the growth of seasonal residents as a first step towards a more in-depth social and economic analysis. Second, it will point to what needs to be examined next to fully investigate the sustainability of these communities.

\section{Methodology for assessing sustainability in the year-round islands of Maine}

Despite the extensive literature on sustainability research, there is no single formula for approaching the subject of community sustainability (Shaffer, 1995; Smith, 2000; Savan \& Sider, 2003; Fraser et al., 2004; Applin, 2009; Singh et al. 2009; Visser, 2010; Lang et al., 2012; James et al., 2012). Indeed, there are almost as many approaches as there are studies. There are a variety of reasons for this but a major factor is that the availability of data often drives the methodological approach. To an extent, this is the case in this research.

The paper largely examines the last two decades in which the communities have changed in a variety of ways, including the expansion of tourism, largely in the form of summer or seasonal residents. Indicators of population change, housing affordability and occupancy, changes in property valuation, median age, and taxable sales are examined descriptively in order to lay a foundation for the measures that best explain the impacts of the changing nature of the islands on community sustainability. The study also examines the issue of food availability on the islands over a ten year period. It is noted that the data here is explanatory in order to lay the ground work for a more quantitative study that will follow in subsequent research. All of these data are combined and utilized to assess the status of sustainability in the islands. In addition, this paper will establish what additional sources of data are needed and what additional research needs to be addressed.

\section{Data sources}

Overall, three major sources of data are utilized. These include: United States Census data, Maine state agency data, and data gathered by the Maine Island Coalition Affordable Housing Subcommittee. Each of these will be examined in depth below. The data from the United States Bureau of the Census draws on historical data from the decennial census of population and housing characteristics with specific focus on the years 1970-2010. Data from the Statistical Abstract and the Agricultural Censuses are also utilized.

The second major source of data is from Maine state agencies. These include data compiled by the State Housing Authority, State Planning Office, State Treasurer's Office and State Revenue Services. In addition, data compiled by the State Historical Society is used.

Finally, primary data collected by the Maine Island Coalition Affordable Housing Subcommittee in 1996 and 2006 is also used. This data on food sales on the islands and in mainland stores was collected with extensive assistance from the University of New England.

The methodologies of data collection for the United States Census and the Maine State Agency data are provided by the agencies themselves in the documents cited below. The methods used to collect data on the availability of commercial food on the islands follows. While the question of how to measure the availability of food appears to be a straightforward enterprise, the reality is more complex. In 1996, a selected focus group of island residents and store owners was convened to discuss how to measure food availability in the islands. Because it would have been prohibitive to examine all sales on all islands for all goods, it was decided to determine the cost of a market basket of the ten most common goods purchased. These 
goods were compared against five additional stores in the islands. At this point, an eleventh item, cat food, was added to the list. Then three Shop 'n Save (now Hannaford) stores were surveyed to establish the base price for the goods at supermarkets. During a three week period, in May 1996, each of the 15 stores on the 14 year-round islands was contacted, and 13 responded with prices. This process was repeated in 2006 except that, in some cases, local residents provided the costs of the 11 goods so that all islands stores were represented.

The next task was to determine consumption rates. Rates vary from region to region, season to season, and by sex and age (Frank et al., 1968; US Census Bureau, 2011; US Department of Agriculture, 2007, 2008, 2011). It was determined that the base unit of consumption would be a family of four: an adult male, an adult female, a male child, and a female child, both between eight and eleven (McReynolds, 1997b). Consumption rates were taken from data used by USDA (USDA, 1995) to calculate allocations of food stamps. In the case of alcohol and cat food, consumption data were taken from national surveys. The consumption rates had to be converted into rates for packaged quantities. For example, if an individual consumes four slices of bread in a day, how far does a loaf of bread go?

Consumption rates were further complicated by the fact that the USDA determined that food consumption rates had changed since the 1996 survey (USDA, 2004). All 1996 data were then recalculated using 2006 rates of consumption. To compare the changes, 2006 data were calculated using 1996 rates. In this research, all rates are based on 2006 consumption levels.

Once consumption rates were established, the next step was to determine the cost of purchasing the goods on the islands and the mainland and to compare the two. The total population of each island was calculated from past census data and then converted to families of four. Consumption rates and costs were determined for a day, week, month, and year.

Problems arise in generating estimates for a variety of reasons. Obviously, not all persons live in a family of four, nor do all families of four have the same consumption rates. In addition, prices in stores vary from week to week and from season to season. That is why the data was collected in a relatively short time and at the same time of year in 1996 and 2006. While potentially fraught with problems, the data provide an important and consistent perspective on the real and potential differences between shopping on-island and off-island.

\section{Literature review and definitions: sustainability, community, sense of place, the role of food availability, and benefits and detriments of seasonal residents}

Since the Brundtland Commission Report (BCR), sustainability has taken centre stage in the discussion of economic and social development. The Commission defined sustainable development as "development that meets the needs of the present without compromising the ability of future generations to meet their own needs" (BCR, 1987, p. x). This work laid the foundation for thousands of books and articles on sustainability (Marjavaara, 2007; Visser, 2009). Indeed, there are now dozens of bibliographies on sustainability in a wide range of areas (Charles \& Benjamin, 1996; Markham, 2003; Myers, 2009; Ng, 2006; Applin, 2009). The cornerstone and focus of this extensive literature on sustainability is the impact on the natural environment (Brown et al., 1988; Bell \& Morse, 2003; Fraser et al., 2004; Cowgill, 2006; Gore, 2006; Stern, 2007; Visser, 2009).

Before there was a focus on the environment, however, there was a concern for the "sustainability" of social life (Dillard et al., 2009). The origins of these concerns can be found in the Morrill Act of 1862 and the development of the United States Land Grant system that established the state agricultural colleges and universities (Brunner, 1966). This system 
produced the "academic trilogy of instruction, research, and service" that has become the foundation of modern education in the United States (Johnson, 1982). While the Morrill Acts of 1962 and 1890 created the instructional component, the Hatch Act, 1887 created the research foundations of the system, and the Smith Lever Act, 1914 established the service element through the creation of the United States Extension Service (True, 1928). The latter was based on a variety of efforts to spread the gospel of good agricultural practices dating back to 1785 in the United States and the establishment of the English Extension Service in 1866. In particular, it drew on the Chautauqua movement of the late 1870s.

While the term sustainability was not used in these early educational endeavors, the spirit of the concept of sustainability was evident in the educational mission of the institutions. The focus, however, was on the economic stability and sustainability of rural regions. The most prominent of the social sustainability research goes back to President Theodore Roosevelt's 1909 Country Life Commission which focused on the out-migration of population from rural areas, the decline in the quality of farm life, and the general decay of rural and isolated communities, as well as the sustainability of agricultural practices (House Committee on Agriculture, 1958).

This work spawned an entire movement: The Country Life Movement (CLM) that was prescient in its concerns and its solutions for rural life that are still evident today (Bailey, 1911). From this movement came hundreds of prescriptions for rural change and development (Vermont Commission on Country Life, 1931). Most early programs avoided economic issues and focused on the prevailing cultural and moral milieu that would lead to rejuvenation and sustainability (McReynolds, 1997a). Liberty Hyde Bailey, a Professor at Cornell University and a key figure in the CLM, believed that the requirements of a good farmer, also applicable to a good fisher, were fourfold: “... the ability to make a full and comfortable living from the land; to rear a family carefully and well; to be of good service to the community; to leave the farm more productive than it was when he $[$ sic] took it" (Bailey, 1911, p. xx). If one replaces "farm" with "sea" this prescription holds today for the island communities of Maine.

Bailey's work and the CLM marked the beginning of what today is called community development and sustainability (McReynolds, 1997a). While his work was comprehensive, efforts at sustainability have moved in new directions to incorporate new concepts such as technology, food, and community systems, and to merge these with environmental concerns (Island Institute, 1997). As with sustainability in general, there are dozens of definitions of community and community sustainability that are often in conflict (Daly \& Cobb, 1989; Lele, 1991; Valentin \& Spangenberg, 2000; Brennan \& Brown, 2008).

The first element of community sustainability is a definition of community itself. This is more elusive than one might think. For many scholars, the study of community, community development, and community sustainability is at a crossroads. Previously dynamic theories do not seem to have kept pace with major social changes (Brennan \& Brown, 2008). New perspectives on community have arisen, such as seeing community moving beyond place with the advent of social networks on-line (Bradshaw, 2008). Green (2008) challenges community specialists to envision community as an outcome of individual, coordinated action. Theodori (2008) on the other hand cautions researchers to identify and account for constraints on individual level collective action. Brennan and Israel (2008) encourage the reader to view community from a perspective of power from the micro, not macro, level. Bridger and Alter (2008) conversely emphasize the need to view the barriers to community in a global context. 
Closely connected to a definition of community is a sense of place. Sense of place or place attachment has become an increasingly important concept in the study of community in general (Scannell \& Gifford, 2010) and islands in particular (Baldacchino, 2006, 2007). Place attachment is the bonding that occurs between individuals and their meaningful environments (Low \& Altman, 1992; Giuliani, 2003). As Scannell and Gifford (2010) note, place attachment becomes increasingly important because the person-place bonds have become fragile as globalization and encroaching environmental problems threaten the existence of, and our connections to, places important to people.

Because of the application of place attachment to many perspectives, a multitude of definitions and conceptualizations has emerged (Proshansky et al., 1983; Giuliani \& Feldman, 1993; Hidalgo \& Hernandez, 2001; Patterson \& Williams, 2005; Stedman, 2006; Walker \& Ryan, 2008). Likewise, a variety of ways of measuring place attachment have also been developed (Williams \& Vaske, 2003; Rollero \& de Piccoli, 2010).

In the literature, there are three points of particular relevance to this study. First, the definition of place is critical. There are two particular strains of place noted in the literature. One focuses on the physical place and can be defined broadly as the environmental setting of the place (Scannell \& Gifford, 2010). The other focuses on the social networks of the place. It is the latter that is the primary perspective employed below. Second, the question arises: do long-term local residents view place differently than those who are seasonal residents (Stedman, 2003)? The literature indicates that a difference does indeed exist and that local residents tend to see place in terms of the social connections and social structures that exist while seasonal residents tend to view place in terms of the environment (Green et al., 1996; Stedman, 2003). Finally, a sense of place has been seen as conceptually different on islands (Baldacchino, 2006; 2007). As Teaiwa (2007) notes, island can be seen as a verb, as it is a way of living. Also, a sense of place in island life can mean a sense of opportunity not limitations (Cambers, 2007). Finally, from Ratter's perspective (2007) islands encompass a uniqueness of a place that is a cultural phenomenon.

In addition to viewing community and an island community specifically from a sense of place, there are a variety of ways in which to view community in the islands of Maine. Clearly, each of these has utility in the examination of community sustainability. For example, community changes in the islands such as the attribution in tax law of the concept of "working waterfronts" (Island Institute, 2011), relied on collective action. Likewise, globalization has both created a class of people who can afford extensive and remote seasonal homes and has created barriers to community power.

To step back, however, the most salient definition of community in the islands of Maine remains a place based definition. As conceptualized earlier, the islands of Maine have a strong historical, cultural, and economic connection to place. James is correct in that, in a provisional definition, 'community' "is a group or network of persons who are connected (objectively) to each other by relatively durable social relations that extend beyond immediate genealogical ties and who mutually define that relationship (subjectively) as important to their social identity and social practice" (James et al., 2012, p. 14). The key issue is simply that self-defined members of that community participate whether directly or indirectly, consciously or unconsciously, in defining the habitus of that community. Still, this is not sufficient to understand the nature of community in the islands of Maine. To this must be added the global component. As will be demonstrated below, the influx of the "world" to the islands has 
changed the very make-up of what the islands are, and has changed the context in which sustainability can be achieved.

The concept of sustainability has been addressed above, but for many, sustainability can only occur at the local level (Yanarella \& Levine, 1992). At the global level, the scale of change required is so great that problems of coordination and cooperation across political units are bound to be too extensive to be successful. To speak of a "sustainable society" or a "sustainable world" requires a level of abstraction that is meaningless to most people. This simple fact makes it extremely difficult to generate and maintain the political will necessary to implement sustainable practices on a large scale (Bridger \& Luloff, 2011).

The focus on local sustainability, however, does not mean the community must be entirely, internally self-sufficient. For small islands this would almost be impossible. Instead, it means three things. First, it means that there must be a network of connectedness among community residents that facilitates the exchanges necessary for the community to survive and sustain itself. This is why James' definition is critical. Second, it means that the community must have consistent access to the resources needed to survive and thrive. For example, all food need not be produced on the island but there must be a consistent and affordable source. The same is true of fuel and other resources. Third, in some cases, it means that some resources must be local. Jobs and housing are good examples of this.

In the context of these definitions of community and sustainability, the availability and access to land as it relates to housing is critical (Satsangi, 2009). This is extremely important on island life where there are external pressures to land/housing consumption (Brookings, 2006; Bryden \& Geisler, 2007; Satsangi, 2007; Lopez Community Land Trust, 2009; Planning Decisions, 2009). On the islands of Maine, the options to move the suburbs, the next community over, or gentrify the inner city, simply do not exist. Either you are on the island, or you are off the island. As a result, any examination of sustainability in the islands of Maine must focus on housing availability, as measured in a variety of ways (Edwards \& Turrent, 2000; Chesire \& Sheppard, 2004; Planning Decisions, 2009).

Although it plays a lesser role in the overall costs and processes of community sustainability, food availability has become as an important issue for island communities (Feenstra, 1997; Five E's Unlimited, 2010; Island Institute, 2011; Sustainable Food Vancouver, 2011). This is particularly true with the rising costs of transportation. In addition, food has emerged as an increasingly important social indicator (Anderson and Cook, 1999). It has been used to measure the consumer price index (Abraham, 1995), poverty (Citro \& Michael, 1995; Kaufman et al., 1997; Willis, 2000), related family income (Hamm, 2008), health (Gillespie \& Smith, 2008), environmental justice (Gottlieb \& Fisher, 1996), environmental change (Ingram \& Liverman, 2010), and the relative advantage of living in inner city, suburban, or rural areas (Ambrose, 1979; Wright et al., 2008). It has also been seen as a force of economic development in island communities (McReynolds, 1997b). Because of these important dynamics, an examination of commercial food availability is used to examine sustainability in the islands of Maine.

Finally, there is the critical issue of whether seasonal residents are beneficial or harmful to the sustainability of small communities. Tourism, recreational, and seasonal development is simultaneously portrayed as a destroyer of culture, undermining social norms and economies, degrading social structures, stripping communities of individuality and as a saviour of the poor and disadvantaged, providing opportunities and economic benefits, promoting social exchange and enhancing livelihoods (Clark, 2007; Simpson, 2008). Clearly, the literature provides a 
variety of differing conclusions (Sem, 1992; Barkley, 1993; Frederick, 1993; Gibson, 1993; Galston \& Baehler 1995; Shaffer, 1995; Jurowski, 1996; King \& Steward, 1996; Marcouiller et al., 1996; Bontron and Lasnier, 1997; Maclis \& Field, 2000; Marcouiller \& Green 2000; Marcouiller et al., 2002; Reeder \& Brown 2005). Most of the literature, however, focuses on perceptions and attitudes of residents toward seasonal development (Kaltenborn et al., 2008; Kitnuntaviwat \& Tang, 2008; Nunkoo \& Raikissoon, 2010).

Of those that have examined the impact of seasonal residents directly, critics argue that tourism and seasonal residents offer seasonal, unskilled low wage jobs that depress local wages and income among other things (Jordan, 1980; Barkley, 1993; Gallent et al., 2003; Clark, 2007). Local poverty increases, local infrastructure is strained (Simpson, 2008), and housing availability declines and costs rise (Galston \& Baehler, 1995; Simpson, 2008). In addition, tax rates increase affecting those with low or fixed incomes (Brown, 2002; Hadsell \& Colarusso, 2009; Reeder \& Brown, 2005). Another concern is that newcomers might have different values than existing residents, leading to conflicts over land use and public policy (Galston \& Baehler, 1995; Clark, 2007). In a related perspective, growth can also erode residents' sense of place, which might reduce support for local institutions, schools and public services (Reeder \& Brown, 2005). The expansion of seasonal residents and tourism can also lead to more equity issues in the use of housing, transportation, infrastructure and community service provisions (Becker and Bradbury, 1994). Finally, issues of the paucity of resources to manage small island development can lead to sustainability problems (McElroy \& de Albuquerque, 2002).

On the other hand, seasonal residents can bring a wide range of benefits to communities (Woodley, 1993). They can spark a housing boom, demands for more goods and services, resulting in a more diversified economy with more high-paying jobs (Johnson \& Thomas, 1990; Bontron \& Lasnier, 1997; Krannich et al., 2006). Income levels could rise as well as other measures of community welfare, while poverty rates could be expected to decline (Gibson, 1995; Reeder \& Brown, 2005). In addition, because incomes increase, tax revenues could increase, which could lead to improved public services (Reeder and Brown, 2005). Developing seasonal homes for the retired has a general benefit in raising incomes and the demand for more services, as well as contributing to a more diversified economy (Chesnutt et al., 1992; Beale \& Johnson, 1998). Others note that an increase in the number of seasonal residents and tourist can also enhance the environmental preservation in a community as well as recreational opportunities (Machlis \& Field, 2000; Marcouiller \& Green, 2000). It is also argued that recreational homeowners play a critical role in generating local business activity (Marcouiller et al., 1996). In short, there are a host of positive possibilities that can be generated by the expansion of tourism, recreational, and seasonal development.

While this research will not provide a definitive answer to these questions, it will lay the foundation for examining many of these perspectives and findings as they apply to the island communities of Maine. An examination of housing is vital (Reeder \& Brown, 2006). In addition, the role of population, tax revenues, and food availability will provide a foundation for the look at sustainability in Maine's year-round islands.

\section{What indicators should be used?}

In undertaking this descriptive examination, there is the issue of what indicators to use to measure or help understand sustainability. As with definitions of community and sustainability, there is a wide range of research that provides insight into what indicators to use to measure sustainability (Bell \& Morse, 1999, 2003; Charles \& Benjamin, 1995; Fraser et al., 2004; Hak, 


\section{S. A. McReynolds}

2007). Indeed, the laundry list of indicators is long and seemingly endless (United Nations, 2004). As Hart (2010) notes, indicators are as varied as the types of systems they monitor. Despite the great variability in indicators, or maybe because of it, it is not always clear what are the best measures to use.

Valentin and Spangenberg (2000) provide a good context for sorting out the available indicators. They note that one must begin with the goal of the measurement and an awareness of the interaction of the economic, environmental, and social dimensions of the communities being measured. Hart (2010) also provides important insights into the indicator selection process. He notes that there are certain characteristics that effective indicators have in common. Effective indicators are relevant, they are easy to understand even by people who are not experts, they are reliable, and most importantly, they are based on accessible data.

The indicators for this research meet the criteria established above (Table 1). For social indicators, data is drawn from the US Bureau of the Census in the years noted. Data for housing affordability, property valuation and taxable sales have been garnered from suitable state agencies. Food prices have been collected from island stores and from supermarkets on the mainland. Combined, these indicators present the most complete analysis available of the status of community sustainability in the year-round islands of Maine (see Map 1).

Map 1: The State of Maine, USA, and including its extensive islands. Source: http://www.nationalatlas.gov/printable/images/pdf/reference/pagegen me.pdf

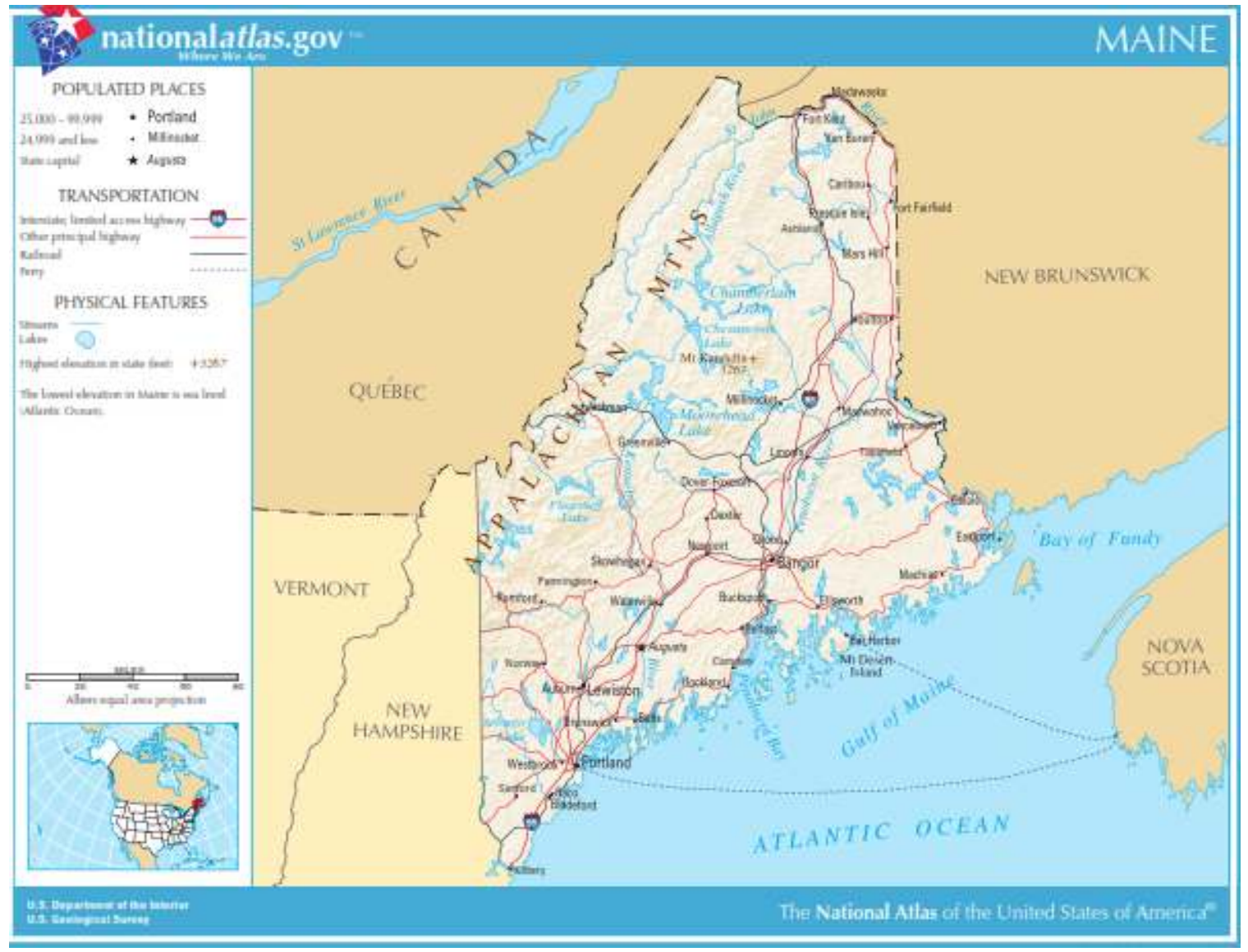


Table 1: Indicators of community sustainability in the islands of Maine.

\begin{tabular}{|c|c|}
\hline \multicolumn{2}{|l|}{$\begin{array}{l}\text { Indicator } \\
\text { Social Indicators } \\
\end{array}$} \\
\hline Population & $\begin{array}{l}\text { Maine Year-Round Island Population Change, 2000-2010 } \\
\text { Peak Population Years for Maine Islands } \\
\text { Median Age on Maine's Year-Round Islands, 1970-2010 } \\
\text { Median Income on Maine's Year-Round Islands, 1999-2009 }\end{array}$ \\
\hline $\begin{array}{l}\mathrm{M} \\
\mathrm{M} \\
\mathrm{Hc} \\
\mathrm{Pe} \\
\mathrm{Hc}\end{array}$ & $\begin{array}{l}\text { Maine Island Housing Change, 2000-2010 } \\
\text { Maine Island Housing Occupancy Change, 2000-2010 } \\
\text { Housing Occupancy in Maine's Islands, 2000-2010 } \\
\text { Percent of Maine Island Vacant Units that are Seasonal Units, 2000-10 } \\
\text { Housing Affordability Index for Maine's Year-Round Islands, 2006-9 }\end{array}$ \\
\hline \multicolumn{2}{|l|}{$\underline{\text { Tax Indicators }}$} \\
\hline $\begin{array}{l}\text { Property Valuation } \\
\text { Taxable Sales } \\
\text { Food Indicators }\end{array}$ & $\begin{array}{l}\text { Maine Year-Round Island Valuations, 2001-2011 } \\
\text { Taxable Sales on Maine's Year Round Islands, 2005-2010 }\end{array}$ \\
\hline Food's Role in Economy & $\begin{array}{l}\text { Cost of Basic Basket of Goods for all year-round Island } \\
\text { Population, } 2006 \\
\text { Percent Food Sales Tax of All Taxable Sales on Maine's Year- } \\
\text { Round Islands, 2005-2010 } \\
\text { Cost Difference between Mainland and Island stores, 1996-2006. }\end{array}$ \\
\hline
\end{tabular}

${ }^{*}$ The source for each construct is detailed in the tables provided separately.

\section{Why study Maine's year round islands?}

To begin with, the question arises: why should the islands of Maine be studied? They are after all a unique and miniscule part of the social fabric of current day Maine. There are at least three responses to this query. First, the islands represent a key part of Maine's history, heritage, and mystique. Second, they are still an important part of the economy. The summer residents are an important cash crop and the islands are home to a critical part of the lobstering industry, a significant export product that is central to the Maine "brand": about 18 percent of island residents hold lobstering licenses, compared to less than one percent of other Maine residents (Island Institute, 2006). Third, from a social science perspective, islands present themselves as self-contained units to examine community sustainability in general (Baldacchino, 2007; Marjavaara, 2007). All too often, in community studies, it is difficult to control for external influences. With islands, the boundaries of impact and research are clearer. Thus, it would be easier to examine community sustainability and food availability in these communities. 


\section{S. A. McReynolds}

\section{The status of community sustainability in Maine's year-round islands}

\section{$\underline{\text { Population }}$}

The total population of Maine's year-round islands declined by just over one percent between 2000 and 2010. It went from 4,488 to 4,441 persons while that of the state of Maine as a whole grew at a rate of 4.2 percent for the decade (Table 2). Although the rate of decline is small, the more interesting point is the great variability among the islands. Five showed double digit increases; while six others experienced declines greater than five percent. This speaks to three points. First, many of the islands are so small that even a small change in population looms large as a percentage. This shows the precarious nature of the population. Second, the decline in total island population is not so precipitous that it means anything significant to the overall population of the islands. Third, however, given the variability by island, e.g. a 60 percent increase in Frenchboro and a 36 percent decline in Isleford, it speaks to the uniqueness of the experiences of each island. To lump them all together belies the history and social and economic realities of each island.

To put the change in island population in historical perspective, with the exception of Long Island, no island even came close to reaching its peak year of its previous population. For all the islands, these were between 1860 and 1920. During this time the state itself was not growing. The fact is: no island since its peak year has even reached fifty percent of its highest census population count. While there is little chance that these islands will reach the population of their "glory" days, it does speak to a long-term issue that shows little chance of population reversal in the foreseeable future (Table 3).

An examination of population change alone does not give as precise a sense of the role of population in sustainability as is possible. Another indicator to examine is median age. This is an important demographic measure of community vitality. In communities with higher median ages, there are fewer children and a greater percent of the population is older. It is not uncommon for communities with high median ages to experience population decline, as community elders pass on without being succeeded by a younger generation. With only one exception, the median for every island from 1970 to 2000 is higher than the state and in each of these years Maine was one of the oldest states in the country. The 2010 data shows a slightly different pattern. Ten islands are older than the state median, four younger, and one the same. There are three explanations for this. First, the state itself is getting older. In fact, it is now the oldest state in the US. Second, the younger islands are smaller and it only takes a few changes to shift the median. Finally, the Bureau of the Census used a different estimation process for median age in 2010 that makes the data from smaller units suspect. But the changes in median age indicate that, like the overall population, there are different patterns on each island. Still, the net effect is that the islands have a higher median age than the state and this can only mean problems for the sustainability of the islands in the future (Table 4).

\section{$\underline{\text { Income }}$}

Income is another issue to examine when looking at sustainability (Table 5). Here, there is an important change between 1999 and 2009. In 1999, the islands overall showed a lower median income than the state and the nation, whereas in 2009 the median income was higher than for the state and the nation. At first glance, this would seem to be a positive development. There 
are, however, three caveats to this conclusion. First, there is great variability among the islands. They range from Frenchboro which showed a decline of 11.5 percent while Peaks and Chebeague showed median increases of over 78 percent. These may be a result of their proximity to Portland. Among the others, there were no discernible patterns. Second, because the seasonal population is not included in the total, one doesn't truly know what the median income is for the islands. Third, as noted above, the different sampling process by the Census Bureau makes the data more suspect. A possible better measure here would be to compare poverty rates or the use of Maine Care, which has been used as a surrogate for poverty rates (Corsello and McReynolds, 2011). As a result, it is difficult to make a definitive assessment regarding the role of the median income data alone and sustainability. More, however, can be said as it connects to housing.

\section{Housing}

While the population in the islands of Maine declined by one percent, the number of housing units increased by 6.8 percent over the decade (Table 6). The state as a whole saw housing increase by 10.7 percent, or two and half times the rate of population growth, while housing in the US as a whole increased by 13.6 percent or 1.41 times the rate of population growth. Relative to population change, the number of housing units on the islands grew faster than for the state or for the country. Housing change was variable across the islands with two islands losing housing and one, Frenchboro, experiencing a 28.8 percent increase. As seen below, Frenchboro also showed the greatest decline in median income. This would seem to indicate a dramatic increase in seasonal units.

The question arises as to why housing change across the islands would be so variable and be growing at such a high rate since the population was declining. The answer lies in the state's motto, "Vacationland." First, it is noted that Maine, with over 20 percent of its housing vacant, has the lowest housing occupancy of any US state. This is due almost exclusively to the fact that there are so many vacation and seasonal units in the state. This is particularly true for the islands of Maine. In both 2000 and 2010, no island had a higher occupancy rate than 45 percent (Table 7). On average, island housing was occupied at a rate of 35 percent in 2000 and only 33.4 percent in 2010. Eleven of the fifteen year-round islands experienced a drop in occupancy rates over the decade. This presents a dilemma for island communities. While it is good that there is more housing, and a higher quality of housing, the down side is that it is primarily seasonal and thus unavailable for year round living.

From the Census data, it is clear that these new units are not available as rental units. In April 2000, over 93 percent of all vacant units on Maine's year-round islands were classified as seasonal units (Table 8). Indeed, on all the islands but one, 90 percent or more of the vacant housing was seasonal. Only about one percent of all the vacant units was available for rent. This is clear evidence that there has been a real shift in the nature of housing on the islands of Maine. The conversion of housing to seasonal units has put upward pressure on the remaining housing by increasing the value of the housing and correspondingly the tax rate on the housing. This has pressured other year-round residents to sell. This shift in the control of housing has also meant a shift or redefinition of the nature of island life in Maine and has drawn island sustainability further into question. This is a major problem for island community sustainability in Maine.

In addition to the general availability of housing, the availability of affordable housing options is extremely important to the survival of island communities. The Maine State Housing 


\section{S. A. McReynolds}

Authority each year generates an affordability index of housing. An affordability index of less than one means that the community is generally unaffordable: a household earning the median income could not afford the median home price. An index of one means that a household earning the median income can afford exactly the median home price.

For the year-round island communities of Maine, housing affordability has been and continues to be a serious problem. In 2006, the overall affordability index was 0.46 or less than half of the capacity to purchase a home at the median price (Table 9). While this index varied across islands, no single island had an index of one. The state index for 2006 was 0.73 . Much the same pattern was evident in 2007 and 2008 where all the islands had an affordability index of 0.50 and 0.37 respectively. This index had moved in a favourable direction by 2009; but, at 0.76 , it was still below affordability and the state index of 0.90 . By 2011, the state index was almost 1.0; but the individual islands showed great variability (Table 10). Chebeague had an index of 0.99 while North Haven and the Cranberry Isles had indexes under 0.20. Overall, from 2009 to 2011, the state affordability index rose while it declined in every island but Monhegan and the index there was only 0.38 . Indeed, while the housing collapse has pushed affordability up in the state, by 2011 it was lower in the islands than ever before. While it is cautioned that a few sales can greatly skew the data, it is clear that housing affordability in the island communities of Maine is an acute problem, particularly when compared to the median income of island residents.

Overall, housing may be the most problematic issue in island community sustainability. The increase in seasonal units, the decline in rental units and the continued decline in housing affordability despite the general collapse in the housing market do not bode well for housing availability to working families on the islands and in turn to island sustainability itself. When it is noted that income has not kept up with housing values, the problem is further exacerbated.

$\underline{\text { Valuation and taxation }}$

Related to housing availability is the issue of valuation. Valuation is the act or process of assessing value or price; an appraisal. Higher valuations mean that both the prices of housing are higher and that the taxes paid on them are higher. For the island communities of Maine, the valuation changes between 2001 and 2006 were staggering. Overall, the islands saw an increase in valuation of over 100 percent compared to the state average of 70 percent (Table 11). This was clearly part of the boom in housing prices that occurred in the first two-thirds of the last decade. Between 2006 and 2011, the overall island valuation change was just 42.6 percent, but this was still much higher than the state rate of 25 percent. For the decade between 2001 and 2011, the islands experienced an increase in valuation of nearly 186 percent while the state saw an increase of 113 percent. Four islands had their valuation rate increase by over 200 percent during this time. Only one island, Frenchboro, was below the state average.

This data adds to concerns over housing and housing affordability on the islands. Combined, they demonstrate three problems for the islands. First, housing is increasingly becoming seasonal. Second, the overall value of housing is increasing at a much faster rate than the income of the islands which is, in fact, declining. Third, while the affordability index has risen in the last two years for the state, it has declined on most islands and therefore affordability remains a serious problem.

The shift of the local economies to seasonal units and an increased reliance on tourism as the main source of economic growth is evident in the data for taxable sales for Maine's yearround islands (Table 12). In 2005, over half of the taxable sales came during the third quarter, 
the summer months and the height of tourism. Every island had at least a third of its taxable sales during this period. Four of the nine islands for which there is data had over two-thirds of their taxable sales during this time period. In 2010, the overall taxable sales for the islands had increased by 7.3 percent but almost all of the increase was during the third quarter. Total intake for this period had increased to 52.4 percent. The pattern among the islands, however, varied. Four islands had a higher share of their taxable sales during this quarter while another four islands had lower shares. This variability speaks to the unique experience of each island. Nonetheless, the overall conclusion is that the islands are increasingly dependent on the summer season which means more tourists and more seasonal residents. The growth in seasonal units has dominated economic and social life on practically every island. And, for the future, these seasonal residents are an essential part of the survival of the islands. The problem is, with seasonal residents as the predominant economic force, what will a "sustainable future" look like on the islands of Maine?

\section{Food availability}

As noted above, food availability is an increasingly important part of community sustainability. The islands of Maine are no exception. As will be examined below, food plays a role in three ways. First, it is a source of employment. Second, food revenues can also be a source of economic development. Third, access to food is critical if a community is going to survive. To begin with, food means jobs. In 2006, the 14 stores employed between 40 and 50 people year round and mostly full-time, with added positions during the high season. While not the major employer on the islands, it was one of the five leading sources of on-island jobs. Fishing was of course first on almost all the islands. The other jobs differed from island to island.

Obviously, an increase in food purchases or sales on the islands can lead to economic development. There are two points raised to examine this. First, the potential total revenue of food just for the 11 items examined is significant (Table 13). Indeed, if everyone on the islands were to buy just bread from the island stores, it would add over one million dollars a year to the island economies. If all these items were purchased exclusively from the island stores, it would generate over five million dollars of income in the islands. If one were to add additional sales the figure would, of course, be even higher. This speaks to the potential of food as a source of economic development.

While this figure is impressive, it does not indicate the real return on food that stays in the community. In fact, food sales have one of the lowest rates of profit and therefore return to the community. Profits measure income after the payments for labour, services, taxes, rents and other costs of operation (Wright, 2013). The supermarket business is a low-margin industry, with the average profit margin for supermarkets typically ranging from 1 to 2 percent. However, natural, organic and gourmet food markets enjoy higher averages: from 3.5 to 6 percent. In 2010, the average profit margin for the supermarket industry was 1.9 percent. Smaller mom and pop grocery stories vary widely in their profit margins depending on hours, types of goods (e.g. they are higher with fresh fish and meats and organic goods) (Reinvestment Fund, 2011). Given the estimates in Table 13, the islands could expect to see profits just exceeding $\$ 100,000$ for the 11 items that are examined here. Given the entire volume of the island stores, assuming island purchases of all of these items, profits could reach as high as one million dollars. This, of course, would be divided disproportionately across the 
islands depending on population and sales. The realities are, however, much lower than this because of purchases on the mainland.

Second, as can be seen from tax revenues, food is contributing to island economic development and this has increased over time (Table 14). The sale of food accounted for 13.6 percent of the total sales tax received on the islands in 2005 and 16.8 percent in 2010. This is a good proxy for the role that food sales play in the local economy. As with other indicators examined, there was great variability across the islands. In 2010, food accounted for 30 percent of all sales on Swans Island; but only 5.1 percent on Monhegan. Over the five year interval from 2005 to 2010, there was a 32 percent increase in the total sales tax collected from food and a 23 percent increase that food taxes played in the overall sales tax collection. This is good news for the islands because it means that more food is being purchased on the islands. In turn, this generates more jobs and more capital. Again, as with profits, the total tax revenue does not provide the full picture. In Maine, the sales tax is five percent, which all goes to the state. Sales tax, along with income from provider taxes, corporate taxes, and use taxes, are used to contribute funds to the local community fund. Historically, five percent of these revenue sharing funds were distributed to communities throughout the state using a revenue sharing formula. The amount distributed has been reduced in recent years (Rodriquez, 2013). Therefore, the largest return on the sales tax could be five percent of the five percent; but the reality is that it is lower than that. This means that, given the estimate used above, for the 11 items examined, if all were purchased on the islands it would yield about $\$ 13,000$ for all of the islands in additional governmental revenue. Clearly, this is not a significant source of economic growth and so, sales tax from food sales will contribute little to sustainability.

Still, food is an important part of community life and its availability is critical to community sustainability. The question arises then, how much food is being purchased on the islands and how does this compare to other food sources? Crucially, the cost of food has been a critical basis of the measurement of poverty in the US for nearly 50 years (Kauffman et al., 1997; Hamm, 2008; U.S. Bureau of the Census, 2010). When combined with the cost of housing, food can be a useful surrogate in determining how much it costs to live on the islands and how much higher this is than mainland living. In other words, island life has added costs.

The price of eleven basic items demonstrates this well (Table 15). For each of the items, the price is clearly higher on the islands. This is to be expected because of transportation costs, lower volume of sales, and the comparison of smaller, owner-operated stores, versus chain stores. In 1996, these items averaged 32.6 percent higher than mainland prices and 31.6 percent in 2006. In addition, there was great variability between the items and across time. Milk had the lowest mainland-island differential in both years, with a difference of 8.2 percent and 7.0 percent respectively. In 1996, Coca-Cola had the highest differential. It was more than double the cost on the islands than on the mainland. By 2006, the difference had declined to a 60 percent difference. By 2006, eggs and toilet paper had become the two most relatively expensive items. Overall, five items were relatively more expensive in 1996 while five items were relatively more expensive in 2006. Only flour remained at about the same level over the two time periods.

Over the ten year period there were noticeable changes in pricing. First, mainland prices changed considerably as did island prices. In addition, the differences between mainland and island prices by product were significant. On the mainland five items saw their prices go up while six went down. For the islands, seven prices went up and four went down. Overall, mainland prices increased by 5.6 percent while, island prices increased only 4.8 percent. What 
is interesting to note is the wide fluctuation in prices in items for both the mainland and the islands. For both the mainland and the islands, flour increased the most (371 and 370 percent) while beer experienced the greatest decline for each (53 and 61 percent).

This speaks to the volatility of food in general but on the islands specifically. It is interesting to note that the islands experienced a slightly lower increase in food prices than did the mainland. While this is not significant, it does indicate that the islands are holding their own in the area of food. Indeed, when one considers the overall increase in tax revenues noted above, it is evident that the island stores are active and growing economic entities.

The stores, however, could make even greater economic contributions to their communities. As noted above, if every year-round island resident were to purchase the eleven basic items examined above for an entire year, it would increase the money spent on islands by over five million dollars. At the same time, if island food cost 31.6 percent more than mainland purchased food, residents need to weigh the personal difference in prices. This is, in part, balanced by the time and transportation costs for islanders to shop on the mainland.

In the end, does the food situation on the islands of Maine contribute to or detract from sustainability? The reality is that it has the capacity to do both. As noted, the cost of food on the islands is approximately 30 percent higher than on the mainland. If all costs of island life were prorated at this rate, then island life would be prohibitive. While islanders have the option of shopping off island there is a significant time issue as well as the cost of transporting themselves and their food. The good news is that over the ten year period between 1996 and 2006, the relative cost has come down slightly. Still, food remains a problem. If one considers that the national poverty rate is based roughly on food costing 30 percent of income, then a doubling of this cost certainly has a major negative impact on the cost of living on the islands. And when median incomes are examined, they do not reflect a 30 percent higher rate. Thus food remains a problem. On the positive side, tax revenues from food are up, indicating that more food is being purchased on the islands. This leaves more local cash at hand and more opportunities for local employment. Food both helps and hinders sustainability.

\section{Conclusion: are the year-round islands of Maine sustainable?}

To begin, it is important to return to the established definition of sustainability. The crux of this comes back to the Brundtland Commission's definition, "development that meets the needs of the present without compromising the ability of future generations to meet their own needs" (BCR, 1987, p. x). Still, there are complexities in this definition as it relates to Maine's islands. In the case of the islands, a key question is; sustainability for whom? Certainly, the islands will continue to exist, new housing will be built, and some form of community life will continue. But again, one asks, for whom? To answer this question, let us review the major findings.

First, population has declined. While the decline is only one percent over the last ten years, it is down significantly from the peak years on all islands but one. In growth driven models of economic development, this is not good for the islands. And, when the median age is considered, the circumstances look worse. As noted, Maine is the oldest state in the union and almost every island has a median age which exceeds the state as well as the nation. This means there is little new blood coming onto the islands and island youths are leaving. Overall, the population situation does not bode well for island sustainability. The question is, is this due to the growth of seasonal residents? The answer is yes, in part, but not completely. As noted below, the growth of seasonal residents has an impact on the housing stock of the islands. Still, seasonal residents do generate jobs in construction, typically pay a higher rate for services, and 
pay higher taxes to the community. The drop in population is probably more a result of transportation costs and job availability. The latter is clearly connected to a decline in fishing in general and specifically to lower lobster prices in recent years.

But as noted, a major reason for the islands' population decline is housing. There has been a 6.8 percent increase in housing on the islands over the last decade. This is about half of the national increase and just under two-thirds of the state's growth. This seems positive if one were to reflect on the declines in some urban areas and in many remote rural places. But the issue is more complex on the islands. First, there is great variability across the islands. Second, there has actually been a decline in housing occupancy rates in the Maine islands with only one third of all housing being occupied year round. The problem is that over 93 percent of the units that are vacant are seasonal and only two percent of these are for rent. In other words, there is little to no housing stock available for community development on the islands. This is further exacerbated by the low housing affordability index. While the housing crash of 2008 has altered this somewhat in a positive direction, the rate of 0.76 is still significantly below the median rate of 1.00 . When taken together, housing remains a critical problem that works against island community sustainability. Again, is this due to the rise in seasonal residents? Here the picture is a little clearer and can be seen to be related to this rise. The low rate of rental units suggests a housing problem, especially for those at either end of the age spectrum: the young just starting out in life, and the elderly often living on fixed incomes.

Income is another measure that was examined and the results here are inconclusive but leaning against sustainability. The inconclusiveness is, in part, a result of the new way in which sampling is done. Still, taking the data at face value, there is a problem. First, as noted above, median income is used in the calculation of the affordability index and this is low. Second, while the island median income has increased and is now above the state and even national level, it is not high enough to offset the cost of island living and island housing in particular. Finally, it is noted that there is great variability across the islands with some islands such as Frenchboro and Isle au Haut having medians that are only minimally above the national thresholds for poverty for a family of four. Thus, income does not augur well for sustainability. But, is this due to the rise in seasonal residents? While the rise in housing costs and tax rates can be connected to a rise in seasonal residents, the overall income situation needs to be connected to the general cost of living on islands, including transportation and utilities, but is also linked to the lack of access to social services such as education and healthcare.

Finally, when food is revisited, the findings are only marginally better than for population, housing and income. More food is being purchased on the islands and this generates more tax revenue and creates more jobs. It also speaks to an improved situation as it relates to food availability. And, relative to the mainland, food prices have dropped slightly from 1996 to 2006. Yet, without a radical shift in island resident purchasing habits, food will remain an issue that cannot generate sustainability on its own. Even if this were to occur, the low rate of profit on food sales will make it hard for food to play a critical role in island community sustainability. The larger question is: what can islanders do to generate their own food supply through community gardens and other local sources? The rise of seasonal residents probably helps with the sale and availability of food. Assuming they have higher incomes, seasonal residents are better able and likely to pay the cost of food on the islands.

Given these results, the most conclusive finding is that seasonal residents have a clear, and largely negative, impact on housing, housing availability, and tax rates. Housing for nonseasonal residents has become more scare, more costly, and subject to higher property taxes. 
Beyond housing, the answer is less conclusive. As noted above, a major issue on the islands is jobs. The seasonal residents do hire construction workers and service providers and do pay at a higher rate. And, as noted, the loss of jobs on the islands is more related to changes in the fishing and lobstering industries than to seasonal residents. While seasonal residents have added some jobs to the communities, it does not appear as if that will be sufficient to sustain the communities. How to add jobs to all island communities is a common critical issue.

In addition, apart from population, housing and jobs, there are other ways in which seasonal residents impact the island communities. On the positive side, it is through paying higher property tax rates and in their sense of place. As noted above, the literature indicates that a difference does exist in the sense of place between year-round and seasonal residents. In the end, the sense of place needs to bring the social connections as noted by year-round residents to the primacy of the environment that is seen by the seasonal residents. Finally, seasonal residents have been known to invest their outside incomes in island projects.

On the negative side, seasonal residents can alter or disrupt social connections as the changes in housing force long term residents to change their living arrangements. In addition, seasonal residents tend to be more skeptical of industrial or commercial developments on the islands. Finally, seasonal residents tend to be less engaged in such social services as health care and education, which are essential to the sustainability of the island communities.

So, to return the original question, based on the data presented here, it is difficult to say whether the island communities in Maine are currently sustainable and if seasonal residents are a benefit or detriment to island sustainability. Indeed, to answer this question would require a great deal more data and analysis. Some of this is detailed below. What can be said is that the islands are in transition and that several factors are critical in that process. First, as noted, the changing number and nature of the population is affecting the islands in a somewhat negative manner. Lower numbers and an aging population do not bode well for sustainability. Second, external to the data presented here, there has been a decline in the fishing industry and improvements don't seem to be in the offing. Third, the factor that is the most important in an examination of sustainability is the rise in housing costs and valuation, and the decline in unit, particularly rental, availability. These factors point to significant concerns in examining sustainability. In both 2000 and 2010, no island had a higher occupancy rate than 45 percent. On average, 35 percent of island housing was occupied in 2000; but only 33.4 percent in 2010 .

To conclude, this research can and should be extended. Here are four suggestions. As discussed earlier, other dynamics of island life need to be addressed. These include: island utilities, transportation costs, and fuel costs such as gasoline and home heating oil. In addition, island communities are burdened with higher costs of maintaining their social infrastructure such as schools, roads, health care facilities, libraries, and community centres. These costs, and related problems (taxes), should also be examined. Finally, job availability, type and development on the islands need to be explored. Indeed, without new jobs, and new types of jobs, it will be hard for the islands to generate long term sustainability, even if housing availability is enhanced.

Ultimately, this data should help hone in on the socio-economic features of the island communities and thus their capacity for sustainability. With few exceptions, the Maine islands as they have historically existed are unsustainable. There is a clear trend towards island "rustification": with a growth in seasonal residents and a decline in year-round residents. It is unlikely that the latter will completely disappear (though this has occurred on Criehaven); but the concept of community as defined here will continue its gradual decline. 
What then can be done to halt, slow, or reverse this trend? The answer to this question is one for the communities involved, organizations such as the Island Institute, and the State of Maine. Some efforts have been made to develop tax relief and other support for "working waterfronts." But, given the findings here, there is much work still to be done to sustain, much less reinvigorate, these island communities.

\section{Acknowledgements}

The author acknowledges Tim Rodriguez (Maine State Treasurer's Office), Bob King (Maine State Housing Authority), and Jerry Stanhope (Maine Department of Revenue) for their help in providing data and explaining how the data were collected. The usual disclaimers apply.

\section{References}

Abraham, K. (1995). The consumer price index: what does it measure? Armonk, 38(3), pp. 5962.

Ambrose, D. M. (1979). Retail grocery pricing: inner city, suburban, and rural comparisons. Journal of Business, 52(1), pp. 95-102.

Anderson, M. D., \& Cook, J. (1999). Community food security: practice in need of theory? Agriculture and Human Values, 16(2), pp. 141-150.

Applin, M. B. (2009). Building a sustainability collection: a selected bibliography. Reference Services Review, 37(3), pp. 313-325.

Bailey, L. H. (1911).The country life movement in the United States. New York: Macmillan.

Baldacchino, G. (2006). Islands, island studies, Island Studies Journal. Island Studies Journal, 1(1), 3-18.

Baldacchino, G. (Ed.) (2007). A world of islands: An island studies reader. Charlottetown, PEI: Institute of Island Studies.

Barkley, D. L. (Ed.) (1993). Economic adaptation: Alternatives for non-metropolitan areas. Boulder CO: Westview Press.

Beale, C. L., \& Johnson, K.M. (1998). The identification of recreational counties in nonmetropolitan areas of the USA. Population Research \& Policy Review, 17(1), pp. 37-53.

Beaver, J. C. (2006). U.S. international borders: Brief facts. Washington, DC. Congressional Research Service: Report for Congress.

Becker, B., \& Bradbury, S. L. (1994). Feedback on tourism and community development: the downside of a booming tourist economy. Journal of the Community Development Society, 29(3), 268-276.

Bell, S., \& Morse, S. (1999). Sustainability indicators: Measuring the immeasurable. London: Earthscan.

Bell, S., \& Morse, S. (2003). Measuring sustainability: Learning from doing. London: Earthscan.

Bontron, J., \& Lasnier, N. (1997). Tourism: A potential source of rural employment. In B. Bollman (Ed.) Rural employment: An international perspective (pp. 427-446).

Wallingford: CAB International.

Bradshaw, T. K. (2008). The post-place community: contributions to debate about the definition of community. Journal of the Community Development Society, 39(1), pp. 5-16.

Brennan, M. A., \& Brown, R. (2008). Community theory: current perspectives and future directions. Journal of the Community Development Society, 39(1), pp. 1-4. 
Brennan, M. A., \& Israel, G. D. (2008). The power of community. Journal of the Community Development Society, 39(1), pp. 82-98.

Bridger, J. C., \& Alter, T. R. (2008). An interactional approach to place-based rural development. Journal of the Community Development Society, 39(1), pp. 99-111.

Bridger, J. C., \& Luloff, A. E. (2011). Sustainable community development: an interactional perspective. Institute for Policy Research and Evaluation, Pennsylvania State University. Retrieved from http://nercrd.psu.edu/community/Legacy/bridger_community.html

Brookings Institution Metropolitan Policy Program. (2006). Charting Maine's future: An action plan for sustainable prosperity and quality places. Washington DC: Brookings Institution.

Brown, B., Hanson, M. E., Liverman, D. M., \& Merideth, R.W. (1988). Global sustainability: toward a definition. Environmental Management, 11(6), pp. 713-719.

Brown, D. M. (2002). Rural tourism: an annotated bibliography. Unpublished manuscript. Retrieved from http://torc.linkbc.ca/torc/downs1/rural tourism.pdf

Brundtland, G. (Ed.), (1987). Our common future: The World Commission on development and the environment. Oxford: Oxford University Press.

Brunner, H. S. (1966). Land-Grant Colleges and Universities: 1862-1962. Washington DC: Department of Health, Education and Welfare: Office of Education.

Bryden, J., \& Geisler, C. (2007). Community-based land reform: lessons from Scotland. Land Use Policy, 24(1), pp. 24-34.

Caldwell, B. (2001). Islands of Maine: Where America really began. Camden ME: Downeast Books.

Cambers, G. (2007). Opportunities, not limitations. In G. Baldacchino (Ed.) A world of islands: An island studies reader (p. 514). Charlottetown, PEI: Institute of Island Studies.

Charles, A. T., \& Benjamin, C. (1995). Sustainability indicators: an annotated bibliography with emphasis on fishery systems, coastal zones and watersheds. Ottawa: SIFR.

Chesire, P. C., \& Sheppard, S. C. (2004). Land markets and land market regulation: progress towards understanding. Regional Science and Urban Economics, 34(6), pp. 619-637.

Chesnutt, J. T., Wilson L., \& Fagan, M. (1992). Attracting the migratory retiree. Auburn AL: Alabama Cooperative Extension Service. Report No. CRD-56.

Citro, C. F., \& Michael, R. T. (Eds.) (1995). Measuring poverty: A new approach. Washington DC: National Academy Press.

Clark, E., Johnson, K., Lundholm, E., \& Malmberg, G. (2007). Island gentrification and space wars. In G. Baldacchino (Ed.) A world of islands: An island studies reader (pp. 483512). Charlottetown, PEI: Institute of Island Studies.

Corsello, M., \& McReynolds, S. A. (2011). Diversion to assets: Interim report for Department of Corrections through the Communities for Children and Youth Initiative of the Governor's Children's Cabinet, funded by the Juvenile Justice Advisory Group. April.

Cowgill, J. (2006). Timeless seeds sustainability strategy. Timeless Seeds Inc. Retrieved from http://www.timelessfood.com/sustainability-strategy.html

Daly, H. E., \& Cobb Jr. J. B. (1989). For the common good: Redirecting the economy toward community, the environment and a sustainable future. Boston MA: Beacon Press.

de Albuquerque, K., \& McElroy, J. L. (1992). Caribbean small island tourism styles. Society and Natural Resources: An International Journal, 3(2), pp. 109-129.

Dillard, J., Dujon, V., \& King, M. (2009). Understanding the social dimension of sustainability. New York: Routledge. 
Edwards, B., \& Turrent, D. (Eds.) (2000). Sustainable housing: Principles and practices. London: E \& FE Spon.

Feenstra, G. W. (1997). Local food systems and sustainable development. American Journal of Alternative Agriculture, 12(1), pp. 28-36.

Five E's Unlimited (2010). A systems approach to sustainability. Retrieved from http://www.eeeee.net/community sustainability.htm

Frank, R. E., Douglas, S. P., \& Polli, R. E. (1968). Household correlates of "brand loyalty" for grocery products. Journal of Business, 41(2), pp. 237-245.

Fraser, E. D. G., Dougill, A. J., Mabee, W. E., Reed, M., \& McAlpine, P. (2004). Bottom up and top down: analysis of participatory processes for sustainability indicator identification as a pathway to community empowerment and sustainable environmental management. Journal of Environmental Management, 78(2), pp. 114-127.

Frederick, M., (1993). Rural tourism and economic development. Economic Development Quarterly, 7(2), 215-224.

Gallent, N., Mace, A., \& Tewdwr-Jones, M. (2003). Dispelling a myth? Second homes in rural Wales. Area, 35(3), pp. 271-284.

Galston, W. A., \& Baehler, K. J. (1995). Rural development in the United States: Connecting theory, practice, and possibilities. Washington DC: Island Press.

Gibson, L. J. (1993). The potential for tourism development in Nonmetropolitan areas. In D. L. Barkley (Ed.) Economic adaptation: Alternatives for nonmetropolitan areas (pp. 145164). Boulder CO: Westview Press.

Gillespie, A., \& Smith, L. E. (2008). Food decision-making framework: connecting sustainable food systems to health and well-being. Journal of Hunger \& Environmental Nutrition, 3(2-3), pp. 328-346.

Giuliani, M. V. (2003). Theory of attachment and place attachment. In T. Bonnes \& M. Bonaiuto (Eds.) Psychological theories for environmental issues (pp. 137-170). Aldershot: Ashgate.

Giuliani, M. V., \& Feldman, R. (1993). Place attachment in a development and cultural context. Journal of Environmental Psychology, 13(3), pp. 267-274.

Gore, A. (2006). An inconvenient truth: The planetary emergency of global warming and what we can do about it. New York: Rodale.

Gottlieb, R., \& Fisher, A. (1996). Community food security and environmental justice: searching for a common discourse. Agriculture and Human Values, 13(3), pp. 23-32.

Green, G. P., Marcouiller, D., Deller, S. Erkkila, D., \& Sumathii, M. R. (1996). Local dependency, land use attitudes, and economic development: comparisons between seasonal and permanent residents. Rural Sociology, 61(3), pp. 427-444.

Green, J. J. (2008). Community development as social movement: A contribution to models of practice. Journal of the Community Development Society, 39(1), pp. 50-62.

Green, J. P. (2001). Amenities and community economic development: Strategies for sustainability. Journal of Regional Analysis and Policy, 31(2), pp. 61-75.

Hadsell, L., \& Colarusso, C. (2009). Seasonal homes and the local property tax: evidence from New York State. The American Journal of Economics and Sociology, 68(2), pp. 581-602.

Hak, T., Moldan, B., \& Dahl, A. L. (2007). Sustainability indicators. London: Island Press.

Hamm, T. (2008). The simple dollar: what's an appropriate home food budget for a family of four? Retrieved from http://www.thesimpledollar.com/2008/09/01/whats-an-appropriatehome-food-budget-for-a-family-of-four 
Hart, M. (2010). Sustainable measures. Sustainable Measures Inc. Retrieved from http://www.sustainablemeasures.com/company

Hidalgo, M. C., \& Hernandez, B. (2001). Place attachment: conceptual and empirical questions. Journal of Environmental Psychology, 21(3), pp. 273-281.

House Committee on Agriculture, Subcommittee on Family Farms. (1958). Hearings on H.R.11844 and H.R. 12239 to establish a Commission on Country Life, 85 Congress, 2nd Session, July 8 and 9.

Ingram J., Ericksen, P., \& Liverman D. (Eds.) (2010). Food security and global environmental change. London: Earthscan.

Island Institute. (1997). Sustaining island communities: The story of the economy and life of Maine's year-round islands. Rockland ME: Island Institute and Maine State Planning Office.

Island Institute (2011). Island agriculture. Retrieved from http://www.islandinstitute.org/islandagriculture.php

Island Institute (2011). Working waterfront. Retrieved from http://www.islandinstitute.org/working_waterfront_access.php

James, P., Nadarajah, Y., Haive, K., \& Stead, V. (2012). Sustainable communities, sustainable development: Other paths for Papua New Guinea. Honolulu HI: University of Hawai'i Press.

Johnson, E. (1981). Misconceptions about the early Land-Grant Colleges. Journal of Higher Education, 52(4), pp. 222-233.

Johnson, P., \& Thomas, B. (1990). Employment in tourism: a review. Industrial Relations Journal, 21(1), pp. 36-48.

Jordan, J. W. (1980). The summer people and the natives some effects of tourism in a Vermont vacation village. Annals of Tourism Research, 7(1), pp. 34-55.

Kaufman, P. R., MacDonald, J. M., Lutz, S. M., \& Smallwood, D. M. (1997). Do the poor pay more for food? Item selection and price differences affect-income household food costs. Food and Rural Economics Division, Economic Research Service, U.S. Department of Agriculture. Agricultural Economic Report No. 759.

Kaltenborn, B. P., Andersen, O., \&_Nellemann, C., (2008). Resident attitudes towards mountain second-home tourism development in Norway: the effects of environmental attitudes. Journal of Sustainable Tourism, 16(6), pp. 664-680.

Kitnuntaviwat, V., \& Tang, J. C. S. (2008). Residents' attitudes, perception and support for sustainable tourism development. Tourism and Hospitality Planning \& Development, 5(1), pp. 45-60.

Krannich, R. S., Petrzelka, P., \& Brehm, J. M. (2006). Social change and well-being in western amenity-growth communities. In W. A. Kandel \& D. L. Brown (Eds.) Population change and rural society (pp. 311-331). Dordrecht: Springer.

Lang, D. J., Wiek, A., Bergmann, M., Stauffacher, M., Martens, P., Moll, P., Swilling, M., \& Thomas, C. J. (2012). Transdisciplinary research in sustainability science: practice, principles, and challenges. Sustainable Science, 7(Supplement 1), pp. 25-43.

Lele, S. (1991). Sustainable development: a critical review. World Development, 19(6), pp. 607621.

Lopez Community Land Trust. (2009). Affordable housing neighborhoods. Retrieved from http://www.lopezclt.org/affordable-housing/ 
Low, S. M., \& Altman, I. (1992). Place attachment: a conceptual inquiry. In I. Altman \& S. M. Low (Eds.) Place attachment (pp. 1-12). New York: Plenum Press.

Maine Island Coalition. Affordable Housing Subcommittee 1996, 2006.

Maine State Housing Authority. Housing Affordability Index. Retrieved from http://www.maine.gov/legis/opla/AffordableHousingStudyrpt.pdf

Maine State Planning Office. (1975). Maine Coastal Program. Maine Island Coastal Registry.

Maine State Revenue Services. Property Valuation. Retrieved from http://www.state.me.us/revenue/

Marcouiller, D. W., Green, G. P., Deller, S. C., \& Sumathi, N. R. (1996). Recreational homes and regional development: a case study from the upper Great Lakes states. No. G3651. Madison WI: University of Wisconsin Extension Report.

Marcouiller, D. W., \& Green, G. P. (2000). Outdoor recreation and rural development. In G. E. Machlis \& D. R. Field (Eds.) Nation parks and rural development: Practice and policy in the United States (pp. 33-49). Washington DC: Island Press.

Markham. V. D. (2003). Issues on population and the environment-I: A bibliography of population and environment resources. Portsmouth NH: Center for Environment and Population.

Marjavaara, R. (2007). Route to destruction? Second home tourism in small island communities. Island Studies Journal, 2(1), pp. 27-46.

McMahon, W. W., \& Melton, C. (1978). Measuring cost of living variation. Industrial Relations, 17(3), pp. 324-332.

McReynolds, S. A. (1997a). Eugenics and rural development: The Vermont Commission on Country Life's program for the future. Agricultural History, 71(3), pp. 300-329.

McReynolds, S. A. (1997b). The community store and island sustainability. In Island Institute Sustaining island communities: The story of the economy and life of Maine's year-round islands (pp. 85-87). Rockland ME: Island Institute \& Maine State Planning Office.

Marcouillier, D. W., Clendenning, J. G., \& Kedzior, R. (2002). Natural amenity-led development and rural planning. Journal of Planning Literature, 16(4), pp. 515-542.

McElroy, J. L., \& de Albuquerque, K. (2002). The problems of managing sustainable tourism small islands. In Y. Apostolopoulos \& D. J. Gayle (Eds.) Island tourism and sustainable development: Caribbean, Pacific, and Mediterranean experiences (pp. 15-31). Westport CT: Praeger.

Myers, J. (2009). Policies that support bridging, bonding and building between government and the social economy in Atlantic Canada. Social Economy and Sustainability Research Network. Retrieved from http://www.msvu.ca/socialeconomyatlantic/pdfs/Documentsandworkingpapers/WorkingP aper200902PolicyScanProcessReport.pdf

Ng, W. W. (2006). Resources for a culture of sustainability. Museums and Social Issues, 1(2), pp. 267-273.

Nunkoo, R., \& Ramkissoon, H. (2010). Small island urban tourism: a residents' perspective. Current Issues in Tourism, 13(1), pp. 37-60.

Patterson, M. E., \& Williams, D. R. (2005). Maintaining research traditions on place: diversity of thought and scientific progress. Journal of Environmental Psychology, 25(4), pp. 361380 .

Planning Decisions, Inc. (2009). An analysis of the recent economic history of Maine's island communities. Rockland ME: Island Institute. 
Proshansky, H. M., Fabian, A. K., \& Kaminoff, R. (1983). Place-identity. Journal of Environmental Psychology, 3(1), pp. 57-83.

Ratter, B. (2007). The uniqueness of islands and the economies of place. In G. Baldacchino (Ed). $A$ world of islands: An island studies reader (p. 522). Charlottetown, PEI: Institute of Island Studies.

Reeder, R. J., \& Brown, D. M. (2005). Recreation, tourism, and rural well-being. US Department of Agriculture, Economic Research Service, Report No. 7.

Rodriquez, T. (2013). Conversation with member of Maine State Treasurer's Office. August 1.

Reinvestment Fund. (2011). Understanding the grocery industry. CDFI Fund. Retrieved from http://www.cdfifund.gov/what we do/resources/Understanding\%20Grocery\%20Industry for $\% 20$ fund 102411.pdf

Rollero, C., \& de Piccoli, N. (2010). Place attachment, identification and environment perception: an empirical study. Journal of Environmental Psychology, 30(2), pp. 198206.

Satsangi, M. (2007). Land tenure change and rural housing in Scotland. Scottish Geographical Journal, 123(1), pp. 33-47.

Satsangi, M. (2009). Community land ownership, housing and sustainable rural communities. Planning Practice \& Research, 24(2), pp. 251-262.

Savan, B., \& Sider, D. (2003). Contrasting approaches to community-based research and a case study of community sustainability in Toronto, Canada. Local Environment: The International Journal of Justice and Sustainability, 8(3), pp. 303-316.

Scannell, L., \& Gifford, R. (2010). Defining place attachment: A tripartite organizing framework. Journal of Environmental Psychology, 30(1), pp. 1-10.

Shaffer, R. (1995). Achieving sustainable economic development in communities. Journal of the Community Development Society, 26(2), pp. 145-154.

Simpson, M. (2008). Community benefit tourism initiatives: a conceptual oxymoron? Tourism Management, 29(1), pp. 1-18.

Singh, R. K. Murty, H. R., Gupta, S. K., \& Dikshit, A. K. (2009). An overview of sustainability assessment methodologies. Ecological Indicators, 9(2), pp. 189-212.

Smith, R. (2000). Readings in research methods in community economic development: an annotated bibliography. Burnaby BC: SFU Community Economic Development Centre.

Stedman, R., (2006). Understanding place attachment among second home owners. American Behavioral Science, 50(2), pp. 187-205.

Stern, N. (2007). The economics of climate change. Cambridge: Cambridge University Press.

Sustainable Food Vancouver. (2011). Retrieved from http://vancouver.ca/peopleprograms/vancouvers-food-strategy.aspx

Teaiwa, T. (2007). To island. In G. Baldacchino (Ed). A world of islands: An island studies reader (p. 514). Charlottetown, PEI: Institute of Island Studies.

Theodori, G. (2008). Constraints to the development of community. Journal of the Community Development Society, 39(1), pp. 83-91.

True, A. C. (1923). A history of agricultural work in the United States, 1785-1923. Washington DC: USDA, GAO.

United Nations. (2007). Indicators of sustainable development: guidelines and methodologies. $3^{\text {rd }}$ edn. New York: United Nations. Retrieved from http://www.un.org/esa/sustdev/natlinfo/indicators/guidelines.pdf

United States Bureau of the Census. (1970). Characteristics of the population, Table 6. 
United States Bureau of the Census. (1980). Characteristics of the population, V1. Table 4.

United States Bureau of the Census. (1990). General population characteristics, V1. Table 1.

United States Bureau of the Census. (2000a). Summary population and housing characteristics, V1. Table 1 \& 11. Matrices H3, H4, H5, H6, H7, and H16.

United States Bureau of the Census (2000b). Data Set: summary File 1, 100\% Data GCT PH1. Population.

United States Bureau of the Census. (2006-2010) Estimates from the American Community Survey 5-Year.

United States Bureau of the Census. (2010a). Income, poverty, and health insurance coverage in the United States: 2010, Report P60, n. 238, p. 61.

United States Bureau of the Census. (2010b). Census redistricting data, (Public Law 94-171) Summary File, Tables P1 and H1.

United States Bureau of the Census (2011). Statistical abstract 2011. Health and nutrition. Food consumption and nutrition. USCB, GAO. Retrieved from http://www.census.gov/compendia/statab/2011/tables/11s0212.pdf

United States Department of Agriculture. (2011). Agricultural fact book, Chapter 2: Profiling food consumption in America. USDA, GAO.

United States Department of Agriculture, Center for Nutrition Policy and Promotion. (1995). Nutrient content of the US food supply, 1909-1995. USDA, GAO.

United States Department of Agriculture, Center for Nutrition Policy and Promotion. (2004). Nutrient content of the US food supply, 1909-2000. USDA, GAO. Retrieved from http://www.cnpp.usda.gov/publications/foodsupply/foodsupply1909-2000.pdf

United States Department of Agriculture, Center for Nutrition Policy and Promotion. (2008). USDA Food Plans: cost of food at home at four levels, US average, February. Retrieved from http://www.cnpp.usda.gov/Publications/FoodPlans/2008/CostofFoodFeb08.pdf

Valentin, A., \& Spangenberg, J. H. (2000). A Guide to community sustainability indicators. Environmental Impact Assessment Review, 20(3), pp. 381-392.

Vermont Commission on Country Life. (1931). Rural Vermont: a program for the future, by two hundred Vermonters. Burlington VT: Vermont Commission on Country Life.

Visser, W. (2010). The top 50 sustainability books. Cambridge: Cambridge University Press.

Walker, A. J., \& Ryan, R. L. (2008). Place attachment and landscape preservation in rural New England: A Maine case study. Landscape and Urban Planning, 86(2), pp. 141-152.

Williams, D. R., \& Vaske, J. J. (2003). Measure of place attachment: validity and generalizability of a psychometric approach. Forest Science, 49(6), pp. 830-840.

Willis, J. (2000). How we measure poverty: a history and brief overview. Oregon Center for Public Policy. Retrieved from http://www.ocpp.org/poverty/how.htm

Woodley, A. (1993). Tourism and sustainable development: the community perspective. In J. G. Nelson, R. Butler \& G. Wall (Eds.) Tourism and sustainable development: Monitoring, planning, managing (pp. 135-146). Waterloo ON: University of Waterloo.

Wright, L., Bitto, E., Oakland, M. J., \& Sand, M. (2008). Accessing food resources: rural urban patterns of giving and getting food. Agriculture \& Human Values, 25(1), pp. 107-119.

Wright, T. (2013). What is the profit margin of a supermarket? Retrieved from http://yourbusiness.azcentral.com/profit-margin-supermarket-17711.html

Yanarella, E. J., \& Levine, R. S. (1992). Does sustainable development lead to sustainability? Futures, 24(8), pp. 759-774. 